\title{
Assessment on variation of performance indicators under phosphorus-starved conditions in a core-set of rice cultivars and their diversity in pup1-linked DNA marker-haplotypes
}

\author{
HSM Jayarathne ${ }^{1}$, PGRG Rathnayake ${ }^{1}$, LT Ranaweera ${ }^{1}$, R Nizam ${ }^{1}$, RMSK Rathnayake ${ }^{1}$, SK Kannangara ${ }^{1}$, \\ UAKS Udawela ${ }^{2}$, CK Weebadde ${ }^{3}$ and SDSS Sooriyapathirana ${ }^{1,4 *}$ \\ ${ }^{I}$ Department of Molecular Biology and Biotechnology, Faculty of Science, University of Peradeniya, Peradeniya. \\ ${ }^{2}$ Rice Research and Development Institute, Bathalagoda. \\ ${ }^{3}$ Department of Plant, Soil and Microbial Sciences, College of Agriculture and Natural Resources, Michigan State University, East Lansing, USA. \\ ${ }^{4}$ Postgraduate Institute of Science, University of Peradeniya, Peradeniya.
}

\begin{abstract}
The development of phosphorous deficiency tolerance (PDT) in rice cultivars is important for sustainable rice production. If the performances (PDT indicators) of the rice cultivars can be correlated with Pup 1 (major QTL linked to PDT in rice) haplotypes, marker assisted breeding (MAB) programmes could be launched to produce phosphorous deficiency tolerant rice varieties. In the present study, 27 rice cultivars (nine landraces and 18 improved varieties) were screened under P-deficient soil conditions in two seasons (Yala and Maha, the major cropping seasons in Sri Lanka) based on shoot dry weight and P utilisation efficiency. To establish the basis for MAB of PDT, the Pupl haplotypes were assessed using 17 Pupl linked DNA markers and sequence polymorphism of the two marker loci, K29 and RM28102. The PDT screening results revealed that the performance of the rice cultivars is season-dependent. The landrace Madathawalu and the old-improved variety H-4 showed the highest trait values for yield, shoot dry weight, and P utilisation efficiency in both Yala and Maha seasons. Remarkably, Madathawalu and H-4 share a common Pup 1 haplotype demonstrating that MAB for PDT is possible using these two rice cultivars as parents. The Pupl linked marker haplotypes and variation of the PDT indicators of the studied cultivars can be used to conduct MAB programmes to develop improved rice varieties.
\end{abstract}

Keywords: Marker assisted breeding, phosphorus efficient rice, phosphorus fertiliser crisis, Pup1 QTL, rice landraces.

\section{INTRODUCTION}

Phosphorus (P) is one of the most important macronutrients for the growth and development of rice plant (Halford, 1997). The problem associated with $P$ as a macronutrient is the limited availability in soil for the plants due to the fixation by $\mathrm{Fe}_{2} \mathrm{O}_{3}, \mathrm{Al}_{2} \mathrm{O}_{3}, \mathrm{CaCO}_{3}$, $\mathrm{MgCO}_{3}$, carboxyl ions, and humic substances (Wang et al., 2013). However, farmers do not recognise the fixation of $\mathrm{P}$ ions within the soil, and they add higher concentrations of $\mathrm{P}$ fertiliser for better growth and development of the plants. The applications of artificial $\mathrm{P}$ fertiliser cause two problems in rice farming (Bulluck \& Ristaino, 2002; O'neil et al., 2012). Sri Lanka spends 0.3 billion US dollars annually ( $1.5 \%$ of GDP) on importing P fertiliser to Sri Lanka, and farmers struggle to purchase these fertilisers due to their higher price (Aluwihare et al., 2016). Therefore, the government has to provide $\mathrm{P}$ fertiliser under a subsidised rate to the farmers creating an extra burden to the national economy. The additional $\mathrm{P}$ fertiliser incorporated to the soil would end up in runoff water; ultimately polluting the water bodies causing eutrophication and health hazards (Bulluck \&

*Corresponding author (sunethuop@gmail.com; (iD) https://orcid.org/0000-0002-5592-1742)

This article is published under the Creative Commons CC-BY-ND License (http://creativecommons.org/licenses/by-nd/4.0/). This license permits use, distribution and reproduction, commercial and non-commercial, provided that the original work is properly cited and is not changed in anyway. 
Ristaino, 2002; O'neil et al., 2012). In addition to the higher price and environmental pollution caused by the heavy dependence on P fertiliser, the currently available $P$ reserves in the world are depleting rapidly and likely to cause a massive fertiliser crisis in the near future (Steen, 1998; Cordell et al., 2009; FAO, 2015). Farmers need large amounts of $\mathrm{P}$ fertiliser in every season; however, $\mathrm{P}$ reserves are rapidly depleting which will place the future rice farming in a futile situation.

The only sustainable solution to face the indisputable $\mathrm{P}$ fertiliser crisis of the future rice farming is to produce $\mathrm{P}$ deficiency tolerant rice varieties through DNA marker assisted breeding (MAB) (i.e., molecular breeding). The genetics of $\mathrm{P}$ deficiency tolerance (PDT) has been studied in detail using worldwide rice germplasm (Ni et al., 1998; Wissuwa et al., 1998). Majumder et al. (1989) first reported that PDT is a quantitatively inherited trait. The major QTL underlying the PDT in rice has been identified and named Phosphorus Uptake 1 (Pup 1) by using a segregating progeny made by crossing $\mathrm{P}$ deficiency tolerant Kasalath and $\mathrm{P}$ deficiency sensitive Nipponbare as the parents (Ni et al., 1998; Wissuwa et al., 1998). Although some other minor QTLs were detected, Pupl was further validated as the major QTL with $80 \%$ effect on the trait PDT. The effect of Pupl was further verified by Chin et al. (2010) and Wissuwa et al. (2002) by incorporating the Pup1 allele of Kasalath to Nipponbare through backcrossing, which demonstrated the increment of $\mathrm{P}$ uptake by $170 \%$ and grain yield by $250 \%$.

Subsequently, the Pupl locus of Kasalath was molecularly characterised with respect to the counterpart allele in Nipponbare. The total length of the Pupl QTL in Kasalath is $423 \mathrm{~kb}$, whereas Nipponbare has $293 \mathrm{~kb}$ allele difference due to the presence of a large deletion of about $130 \mathrm{~kb}$ (Heuer et al., 2009). The molecular markers within Pupl, the candidate genes and their relative physical and mapping distances were characterised and are publicly available (Chin et al., 2010; 2011). One of the drawbacks in Pupl characterisation studies is the underutilisation of country-specific improved varieties and traditional landraces. It has been observed that such locally adapted rice varieties perform impressively in infertile soils. The local varieties may contain additional QTLs to Pup1 or hitherto unknown haplotypes of Pup1.

The old improved rice cultivars and landraces in Sri Lanka possess novel Pupl haplotypes compared to the Kasalath type Pupl haplotype (Aluwihare et al., 2016; 2018). This observation highlights the significance of studying the important local rice landraces and varieties (i.e., cultivars) for PDT and then detecting their Pupl haplotypes with respect to the association with PDT conferring traits. Thus, MAB can be swiftly carried out within the regional rice breeding programmes because of the availability of locally present PDT promoting haplotypes. They would provide a strong basis for selecting more efficient rice varieties for local needs rather than just examining for the presence of Pupl haplotype in the lines to be selected. Therefore, the present study, was aimed at screening a set of rice landraces and improved rice varieties in Sri Lanka for PDT, identify their maker haplotypes of Pupl and characterise two key co-dominant sequence tagged sites (STS) within Pupl locus to facilitate MAB of rice for PDT.

\section{METHODOLOGY}

\section{Growing seasons}

Based on the two seasons of monsoonal rains in Sri Lanka, rice farming is conducted under two major cropping seasons, namely, Yala and Maha. The growing season Yala runs from early April to late August with

Table 1: Climatic parameters of the field location during the two seasons

\begin{tabular}{|c|c|c|c|c|c|}
\hline $\begin{array}{l}\text { Location and global } \\
\text { positioning system } \\
\text { (GPS) coordinates }\end{array}$ & $\begin{array}{l}\text { Agro-ecological } \\
\text { zone }(\mathrm{AEZ})^{\mathrm{a}}\end{array}$ & Season & $\begin{array}{c}\text { Temperature } \\
\left({ }^{\circ} \mathrm{C}\right)\end{array}$ & $\begin{array}{c}\text { Total rainfall }(\mathrm{mm}) \\
\text { of the season }\end{array}$ & $\begin{array}{c}\text { Sunshine hours } \\
\text { (h/day) }\end{array}$ \\
\hline & & Maha (Sep-Mar) & $21.3-32.4$ & 479.6 & $7.6-8.0$ \\
\hline \multirow[t]{2}{*}{$\left(\mathrm{N}^{\circ} 31^{\prime} 49.21^{\prime \prime}\right.$} & & $2016 / 2017$ & & & \\
\hline & IL1a & & & & \\
\hline $\left.\mathrm{E} 80^{\circ} 26^{\prime} 25.49^{\prime \prime}\right)$ & & Yala (Apr -Aug) 2017 & $24.3-32.2$ & 408.4 & $6.2-8.0$ \\
\hline
\end{tabular}

a AEZ classification was obtained from the Department of Agriculture, Sri Lanka (http://www.agridept.gov.lk/). IL: Intermediate low 
the Southwest monsoonal rains and the growing season. Maha runs from late September to early March with the Northeast monsoonal rains (DOA, 2006). The growing and climatic conditions of the field where the trial was conducted are given in Table 1 . The trials were conducted in Maha and Yala seasons of the year 2016/2017.

Table 2: Rice genotypes screened for phosphorous deficiency tolerance

\begin{tabular}{|c|c|c|c|}
\hline $\begin{array}{l}\text { Name of the } \\
\text { genotype }\end{array}$ & $\begin{array}{l}\text { Type of } \\
\text { cultivar }\end{array}$ & $\begin{array}{l}\text { Naturally preferred } \\
\text { growing condition }\end{array}$ & Key characteristics \\
\hline Herath banda & $\mathrm{L}$ & UL & Red pericarp, high amylose content \\
\hline Kuruluthudu & $\mathrm{L}$ & UL & $\begin{array}{l}\text { Red pericarp, good cooking quality, rich in protein and fibre, enhance male sexual } \\
\text { potency, improved bladder function }\end{array}$ \\
\hline Madathawalu & $\mathrm{L}$ & UL & $\begin{array}{l}\text { Red pericarp, comparatively low glycemic index, recommended in Ayurvedic } \\
\text { treatments }\end{array}$ \\
\hline Masuran & $\mathrm{L}$ & UL & Red pericarp, bold grain type \\
\hline Pachchaperumal & $\mathrm{L}$ & UL & Red pericarp, rich in protein, recommended for diabetes and cardiovascular diseases \\
\hline Rath suwandel & $\mathrm{L}$ & UL & Red pericarp \\
\hline Rathdel & $\mathrm{L}$ & UL & $\begin{array}{l}\text { Recommended for cirrhosis, prevent formation of stones in the bladder and gall } \\
\text { bladder }\end{array}$ \\
\hline Sulai & $\mathrm{L}$ & UL & Red pericarp, good cooking quality, resistant to brown plant hopper \\
\hline Thatu vee & $\mathrm{L}$ & UL & Red pericarp \\
\hline At308 & NI & LL & Suitable to grow under rain fed and irrigated farming conditions \\
\hline At309 & NI & LL & $\begin{array}{l}\text { White pericarp, moderately resistant and resistant to blast and moderately resistant } \\
\text { to brown plant hopper }\end{array}$ \\
\hline At311 & NI & LL & Red elongated pericarp \\
\hline At354 & NI & LL & White pericarp \\
\hline At373 & NI & LL & White pericarp, short round grain, good cooking quality, resistance to gall midge \\
\hline $\mathrm{Bg} 310$ & NI & LL & $\begin{array}{l}\text { White pericarp, high amylose content, resistant to blast, gall midge and brown plant } \\
\text { hopper }\end{array}$ \\
\hline $\mathrm{Bg} 359$ & NI & LL & $\begin{array}{l}\text { Resistance to gall midge } 1 \text { and } 2 \text {, rice blast disease and bacterial leaf blight, } \\
\text { moderately tolerant to brown plant hopper }\end{array}$ \\
\hline $\operatorname{Bg} 366$ & NI & LL & White pericarp, non-glutinous endosperm, resistant to bacterial leaf blight \\
\hline Bg369 & NI & LL & White pericarp, long grain shape, recommended for saline affected areas \\
\hline Bw363 & NI & LL & White pericarp, moderately tolerant to brown plant hopper, blast and gall midge \\
\hline Bw367 & NI & LL & Short round grain type, moderately tolerant to ion toxicity, tolerant for lodging \\
\hline Bw452 & NI & LL & $\begin{array}{l}\text { Red pericarp, little tall, tolerant to bronzing and submergence in low country wet } \\
\text { zone }\end{array}$ \\
\hline Ld356 & NI & LL & Red pericarp, short round grains \\
\hline $\operatorname{Ld} 365$ & NI & LL & White pericarp \\
\hline $\operatorname{Ld} 371$ & NI & LL & $\begin{array}{l}\text { Tolerant to seed discolourations and neck blast, resistant/moderately resistant to } \\
\text { blast, gall midge and brown plant hopper }\end{array}$ \\
\hline $\mathrm{H}-10$ & OI & UL & Red pericarp, less photoperiod sensitivity \\
\hline $\mathrm{H}-4$ & OI & UL & Resistant to rice blast disease \\
\hline $\mathrm{H}-7$ & OI & UL & Better grain quality, higher response to nitrogen \\
\hline
\end{tabular}

Source: Rice Research and Development Institute, Bathalagoda, Sri Lanka

L: landrace; NI: newly improved; OI: old improved (during 1950's); UL: upland; LL: lowland 


\section{Rice cultivars, plant establishment and maintenance}

The breeder seeds of 27 rice cultivars [landraces (L), old-improved (OI) and newly-improved (NI) varieties] were obtained from the Rice Research and Development Institute (RRDI) Bathalagoda, Sri Lanka (Table 2). Seeds were germinated and established in non-fertilised soil at RRDI, where a separate block of the field is maintained as non-fertilised soil for the last 45 years (Kumaragamage \& Indraratne, 2011; Sirisena \& Wanninayake, 2014).

\section{Data collection}

\section{Growth and yield parameters}

The plant height (PLH), number of tillers (NT), flag leaf length (FLL), flag leaf width (FLW) and yield per plant were collected for both seasons. PLH was measured from the base of the plant to the tip of the top leaf in centimeters. These measurements were taken at the flowering stage. NT was also recorded at the flowering stage for all the cultivars. FLL and FLW were measured after the flowering stage. The FLL was measured from the bottom of the leaf to the tip in centimeters. Maximum width of the leaf was taken as the FLW and measured in millimeters. Aerial parts of the plant were used to obtain the shoot dry weight (SDW). The plants were harvested at the flowering stage and the shoot parts were washed with distilled water and oven dried at $60{ }^{\circ} \mathrm{C}$ to obtain a constant dry weight (grams).

\section{PDT indicators}

The plants from each cultivar were collected at the harvesting stage, roots were removed, and oven dried until a constant weight was obtained. Weight of the oven dried samples were measured and taken as the SDW in grams. Oven dried shoots were ground into fine powder and a total of $0.5 \mathrm{~g}$ of powdered shoot material was taken for the digestion. The process of digestion was carried out using an acid mixture of conc. $\mathrm{HNO}_{3}$ and conc. $\mathrm{HClO}_{4}$ in a ratio of $4: 1$, respectively. The shoot $\mathrm{P}$ concentration (SPC) was obtained as the amount of P (mg) in $1 \mathrm{~g}$ of shoot dry matter by following the phosphovanadate method described in Hanson (1950). The shoot phosphorous uptake (SPU) was calculated using the formula described in Fageria et al. (1988) and Gunes et al. (2006). SPU was calculated for each variety in $\mathrm{mg}$ per plant.

Phosphorus utilisation efficiency (PUE) was calculated in grams per milligrams, in other words biomass produced per unit $\mathrm{P}$ accumulated in shoot (Rose \& Wissuwa, 2012). Establishment of DNA marker haplotypes for the
Pup1 locus

\section{DNA extraction and PCR}

Immature leaf samples of rice cultivars (Table 2) were collected and subjected to DNA isolation using Dneasy ${ }^{\circledR}$ plant mini kit (Qiagen, Solna, Sweden). The isolated DNA of each cultivar was subjected to PCR amplification with the markers developed for Pup1 QTL (Table 3). The PCR conditions were provided in the Thermal Cycler (Takara, Japan) as follows; initial denaturation at $94^{\circ} \mathrm{C}$ for $5 \mathrm{~min}$, then 35 cycles at $94{ }^{\circ} \mathrm{C}$ for $30 \mathrm{~s}$ for denaturation, primer annealing temperature (Ta) (Table 3 ) for $90 \mathrm{~s}$, and $72{ }^{\circ} \mathrm{C}$ for $2 \mathrm{~min}$, finally extension at $72^{\circ} \mathrm{C}$ for $10 \mathrm{~min}$. The PCR products were size separated using ethidium bromide stained $2.5 \%$ agarose gel electrophoresis.

\section{Detection of the sequence polymorphism in K29 and RM28102}

The PCR products of K29 and RM28102 were purified using QIAquick ${ }^{\circledR}$ PCR Purification Kit (Catalog No: 28104, Qiagen, Hilden, Germany). The purified PCR products of the markers were subjected to $3 \times$ Sanger sequencing in Macrogen Inc., South Korea.

\section{Data analysis}

\section{Growth, yield and PDT parameters}

All the tested parameters were subjected to general linear model procedure (GLM) and Duncan's mean separation in SAS Version 9.4 (SAS Institute Cary, NC, USA).

\section{Pup1 DNA haplotypes}

Based on the binary data for DNA marker polymorphism, a dissimilarity matrix was constructed using the unweighted pair group method with arithmetic means (UPGMA) (Nei \& Kumar, 2000) in Phylip package v3.697 (Felsentein, 2005) and the tree was visualised using FigTree v1.4.3. (Rambaut, 2018).

\section{Detection of K29 and RM28102 haplotypes}

Two separate alignments were constructed for the markers RM28102 and K29 using MEGA v7 software (Kumar et al., 2016) and the dendrograms were constructed using UPGMA algorithm. The obtained sequences were aligned using the MEGA software with a reference sequence obtained from the GenBank (www.ncbi.nlm.nih.gov; https://www.ncbi.nlm.nih. gov/assembly/GCA_009829375.1). The SNPs and the 
INDELs were identified from the generated multiple sequence alignment. The generated RM28102 and K29 sequences were stored under GenBank Accession Nos.
MK890248-MK890274 and MK890275-MK890301, respectively (PopSet IDs 1789811496 and 1789811549, respectively).

Table 3: Pupl linked markers assessed in the present study

\begin{tabular}{|c|c|c|c|c|}
\hline Marker & Forward and reverse primer sequences & Band size (bp) & $\mathrm{Ta}\left({ }^{\circ} \mathrm{C}\right)$ & Reference \\
\hline K20 & $\begin{array}{l}\text { TCAGGTGATGGGAATCATTG } \\
\text { TGTTCCAACCAAACAACCTG }\end{array}$ & 240,243 & 55 & \multirow{11}{*}{ Chin et al. (2010) } \\
\hline$K 29$ & $\begin{array}{l}\text { CCATAGTAGCACAAGAAACCGACA } \\
\text { GCTTCAATGAGCCCAGATTACGAA }\end{array}$ & 850,491 & 55 & \\
\hline$K 41$ & $\begin{array}{l}\text { TGATGAATCCATAGGACAGCGT } \\
\text { TCAGGTGGTGCTTCGTTGGTA }\end{array}$ & 382 & 57 & \\
\hline$K 42$ & $\begin{array}{l}\text { CCCGAGAGTTCATCAGAAGGA } \\
\text { AGTGAGTGGCGTTTGCGAT }\end{array}$ & 918 & 57 & \\
\hline$K 43$ & $\begin{array}{l}\text { AGGAGGATGAGCCTGAAGAGA } \\
\text { TCGCACTAACAGCAGCAGATT }\end{array}$ & 912 & 57 & \\
\hline$K 46$ & $\begin{array}{l}\text { TGAGATAGCCGTCAAGATGCT } \\
\text { AAGGACCACCATTCCATAGC }\end{array}$ & 523 & 57 & \\
\hline$K 48$ & $\begin{array}{l}\text { CAGCATTCAGCAAGACAACAG } \\
\text { ATCCGTGTGGAGCAACTCATC }\end{array}$ & 847 & 57 & \\
\hline K52 & $\begin{array}{l}\text { ACCGTTCCCAACAGATTCCAT } \\
\text { CCCGTAATAGCAACAACCCAA }\end{array}$ & 505,700 & 57 & \\
\hline K59 & $\begin{array}{l}\text { GGACACGGATTCAAGGAGGA } \\
\text { TGCTTTCCATTTGCGGCTC }\end{array}$ & 550 & 57 & \\
\hline$R M 28102$ & $\begin{array}{l}\text { CACTAATTCTTCGGCTCCACTTTAGG } \\
\text { GTGGAAGCTCCGAGAAAGTGC }\end{array}$ & 168 & 55 & \\
\hline$R M 28073$ & $\begin{array}{l}\text { GTGTTGGTGGTGATGAAGCAAGG } \\
\text { GGACGAAGGATGTATGTGTCTGTACC }\end{array}$ & 656 & 55 & \\
\hline$K 46-K 1$ & $\begin{array}{l}\text { TGAGATAGCCGTCAAGATGCT } \\
\text { TGAGCCAGTAGAATGTTTTGAGG }\end{array}$ & 342 & 57 & \multirow{5}{*}{$\begin{array}{l}\text { Pariasca-Tanaka et al. } \\
\text { (2014) }\end{array}$} \\
\hline$K 46-K 2$ & $\begin{array}{l}\text { CTGAAGTGAAAAGAATGACTAA } \\
\text { TGAGCCAGTAGAATGTTTTGAGG }\end{array}$ & 110,433 & 57 & \\
\hline$K 46-3$ & $\begin{array}{l}\text { TCCAAAGATCTCTGATTTTGGC } \\
\text { GCTTTCCAACATCTCAAGGACT }\end{array}$ & 400 & 57 & \\
\hline$K 46-C G 1$ & $\begin{array}{l}\text { CTAGAGTATCTCCACAGTCGTT } \\
\text { AAGGACCACCATTCCATAGC }\end{array}$ & 258 & 57 & \\
\hline$K 46-C G 2$ & $\begin{array}{l}\text { CCGAAGTAAGAAGAATGACGGA } \\
\text { TGATCCAGGAGAATGTTTTGTGG }\end{array}$ & 130,433 & 57 & \\
\hline Ba76H14_7154 & $\begin{array}{l}\text { GAAACGGGGTCAAATAAGC } \\
\text { GGGTTCGTCCAACAGGAGTA }\end{array}$ & 292,259 & 55 & Heuer et al. (2009) \\
\hline
\end{tabular}

\section{RESULTS AND DISCUSSION}

\section{Selection of cultivars}

The identification of $\mathrm{P}$ deficiency tolerant rice cultivars is important to use as parents in breeding programmes and to recommend as varieties for organic rice farming.
Even in conventional rice farming, $\mathrm{P}$ efficient rice cultivars are important to reduce the cost of production and environmental pollution, and as answers to the $\mathrm{P}$ fertiliser crisis in the future (Wissuwa \& Ae, 2001; Cordell et al., 2009; O'neil et al., 2012). Worldwide rice genetics and breeding programmes have screened diverse germplasm for PDT. In Sri Lanka, Aluwihare 
et al. (2016) have screened 30 rice cultivars for PDT. In the present study, 27 cultivars were assessed including a few varieties (Rathdel, H-4, H-7, H-10, At354, Ld356) from Aluwihare el al. (2016) to further identify useful $\mathrm{P}$ deficiency tolerant parent/cultivars for rice breeding and production in Sri Lanka. Nine landraces were incorporated into the present study because they have untapped genetic resources for various resistance or tolerance traits (Herath et al., 1982; Fageria \& Santos, 2002; Chin et al., 2010). Fifteen newly improved varieties were also incorporated to check the PDT. As indicated in Table 2 and the rice varietal descriptions in RRDI Sri Lanka, the selected rice cultivars in the present study are identified as important parents for rice breeding and varieties for production in Sri Lanka. As explained by Majumder et al. (1989) and in subsequent studies, PDT is a quantitative trait (Wissuwa et al., 1998; 2002; Ni et al., 1998; Wissuwa \& Ae, 2001) and heavily dependent on the Pupl haplotype present in the cultivar, environment and the environment $\times$ QTL interaction.

\section{Plant height and number of tillers}

In the Maha season, mean PLH at flowering stage was significantly higher in Kuruluthudu and Rathdel compared to the rest of the cultivars. Whereas in Yala

Table 4: Variation of the plant height (PLH) and no. of tillers (NT) of the rice cultivars under P starved field condition

\begin{tabular}{|c|c|c|c|c|c|}
\hline \multirow[b]{2}{*}{ Type } & \multirow[b]{2}{*}{ Cultivar } & \multicolumn{2}{|c|}{ PLH (cm) } & \multicolumn{2}{|c|}{ NT } \\
\hline & & Maha & Yala & Maha & Yala \\
\hline \multirow[t]{9}{*}{ Landrace } & Herath banda & $79.0^{\text {bcde }}$ & $93.7^{\mathrm{ef}}$ & $2.4^{\mathrm{h}}$ & $3.4^{\text {bcde }}$ \\
\hline & Kuruluthuda & $120.3^{\mathrm{a}}$ & - & $2.6^{\mathrm{gh}}$ & - \\
\hline & Madathawalu & $79.6^{\mathrm{bcd}}$ & $67.3^{\mathrm{klm}}$ & $5.0^{\mathrm{abcd}}$ & $2.0^{\text {ghij }}$ \\
\hline & Masuran & $83.9^{\mathrm{bc}}$ & $94.5^{\mathrm{ef}}$ & $3.9^{\text {cdefgh }}$ & $3.0^{\text {cdefg }}$ \\
\hline & Pachchaperumal & $73.3^{\text {cdef }}$ & $115.2^{\mathrm{b}}$ & $3.6^{\text {cdefgh }}$ & $3.6^{\text {abcd }}$ \\
\hline & Rathdel & $111.6^{\mathrm{a}}$ & - & $2.5^{\mathrm{h}}$ & - \\
\hline & Rath suwandel & $56.9^{\text {hij }}$ & $107.2^{\text {cd }}$ & $4.5^{\text {abcdef }}$ & $2.5^{\text {efgh }}$ \\
\hline & Sulai & $78.6^{\text {bcde }}$ & $87.7^{\text {ghi }}$ & $2.6^{\mathrm{gh}}$ & $1.5^{\mathrm{hij}}$ \\
\hline & Thatuvee & $91.8^{\mathrm{b}}$ & $84.6^{\mathrm{hi}}$ & $2.3^{\mathrm{h}}$ & $1.5^{\mathrm{hij}}$ \\
\hline \multirow[t]{15}{*}{ Newly Improved } & At308 & $54.4^{\mathrm{ij}}$ & $65.1^{\mathrm{lmn}}$ & $3.5^{\text {cdefgh }}$ & $2.1^{\text {fghij }}$ \\
\hline & At309 & $59.2^{\text {ghij }}$ & $61.8^{\mathrm{no}}$ & $5.9^{\mathrm{ab}}$ & $2.8^{\operatorname{defg} g}$ \\
\hline & At311 & $61.1^{\text {fghi }}$ & $57.8^{\circ}$ & $5.3^{\mathrm{abc}}$ & $3.5^{\text {bcde }}$ \\
\hline & At354 & $69.3^{\text {defgh }}$ & $71.1^{\mathrm{jk}}$ & $4.9^{\text {abcde }}$ & $3.8^{\text {abcd }}$ \\
\hline & At373 & $51.9^{\mathrm{ij}}$ & $64.3^{\mathrm{mn}}$ & $5.8^{\mathrm{ab}}$ & $2.3^{\text {fghi }}$ \\
\hline & Bg310 & $46.0^{\mathrm{j}}$ & $69.4^{\mathrm{ikl}}$ & $2.8^{\mathrm{fgh}}$ & $2.8^{\operatorname{defg} g}$ \\
\hline & Bg359 & $86.3^{\mathrm{bc}}$ & $62.0^{\text {no }}$ & $3.5^{\text {cdefgh }}$ & $3.0^{\text {cdefg }}$ \\
\hline & $\mathrm{Bg} 366$ & $65.3^{\text {efghi }}$ & $73.7^{\mathrm{j}}$ & $3.0^{\mathrm{fgh}}$ & $3.1^{\text {bcdef }}$ \\
\hline & $\mathrm{Bg} 369$ & $72.0^{\text {cdefg }}$ & $70.9^{j}$ & $3.1^{\text {efgh }}$ & $2.0^{\text {ghij }}$ \\
\hline & Bw363 & $81.8^{\mathrm{bcd}}$ & $83.4^{\mathrm{i}}$ & $3.9^{\text {cdefgh }}$ & $3.0^{\text {cdefg }}$ \\
\hline & Bw367 & $68.4^{\text {defgh }}$ & $97.4^{\mathrm{e}}$ & $3.4^{\text {defgh }}$ & $1.1^{\mathrm{j}}$ \\
\hline & Bw452 & $53.5^{\mathrm{ij}}$ & $72.7^{\mathrm{j}}$ & $2.9^{\mathrm{fgh}}$ & $2.3^{\mathrm{fghi}}$ \\
\hline & Ld356 & $74.0^{\text {cdef }}$ & $147.6^{\mathrm{a}}$ & $4.0^{\text {cdefgh }}$ & $1.4^{\mathrm{ij}}$ \\
\hline & Ld365 & $63.3^{\text {fghi }}$ & $108.7^{\mathrm{c}}$ & $4.4^{\text {bcdefg }}$ & $3.9^{\mathrm{abc}}$ \\
\hline & Ld371 & $81.4^{\text {bcd }}$ & $88.9^{\mathrm{gh}}$ & $6.1^{\mathrm{a}}$ & $4.6^{\mathrm{a}}$ \\
\hline \multirow[t]{3}{*}{ Old Improved } & $\mathrm{H}-10$ & $86.4^{\mathrm{bc}}$ & $71.3^{\mathrm{jk}}$ & $4.9^{\text {abcde }}$ & $4.2^{\mathrm{ab}}$ \\
\hline & H-4 & $82.3^{\text {bcd }}$ & $91.2^{\mathrm{fg}}$ & $4.0^{\text {cdefgh }}$ & $2.8^{\operatorname{defg} g}$ \\
\hline & $\mathrm{H}-7$ & $82.5^{\text {bcd }}$ & $103.1^{\mathrm{d}}$ & $5.1^{\mathrm{abcd}}$ & $4.0^{\mathrm{abc}}$ \\
\hline
\end{tabular}

Means denoted by same letters within each column are not significantly different at $p<0.05$ 
season, the significantly higher PLH was reported in LD356. Mean NT was significantly higher in LD371 in both Yala and Maha seasons ( $<$ 0.05) (Table 4). The landraces Kuruluthudu and Rathdel did not flower in Yala season because of their photoperiod sensitivity and remained in the vegetative phase; thus, their PLH and NT were not recorded and included in the analysis. The parameters PLH and NT have shown high variability and cultivar specificity indicating that they are less sensitive to PD imposed (Table 4).

\section{Flag leaf size and yield}

The landrace Herath banda and the newly improved variety BW452 took at least 8-10 weeks to flower and produce panicles in Yala season. By that time all the other plots were harvested, and therefore the plots of Herath banda and BW452 were heavily exposed to birds, pests, and diseases. Thereby we were unable to collect the yield data for these two cultivars in Yala season (Table 5).

Table 5: Variation of the size of flag leaf [flag leaf length (FLL) and width (FLW)] and yield under P starved field condition

\begin{tabular}{|c|c|c|c|c|c|c|c|}
\hline \multirow[t]{2}{*}{ Origin } & \multirow[t]{2}{*}{ Cultivar } & \multicolumn{2}{|c|}{ FLL (cm) } & \multicolumn{2}{|c|}{ FLW (cm) } & \multicolumn{2}{|c|}{ Yield (g/plant) } \\
\hline & & Maha & Yala & Maha & Yala & Maha & Yala \\
\hline \multirow[t]{9}{*}{ Landrace } & Herath banda & $24.06^{\mathrm{de}}$ & $40.62^{\mathrm{a}}$ & $7.94^{\text {cdef }}$ & $12.63^{\mathrm{bc}}$ & $3.40^{\mathrm{op}}$ & $-* *$ \\
\hline & Kuruluthudu & $37.37^{\mathrm{a}}$ & -* & $11.44^{\mathrm{bc}}$ & $-*$ & $8.98^{\mathrm{bc}}$ & $-*$ \\
\hline & Maathawalu & $26.08^{\mathrm{cd}}$ & $38.02^{\mathrm{ab}}$ & $8.81^{\text {cdef }}$ & $12.50^{\mathrm{bc}}$ & $7.97^{\mathrm{cd}}$ & $11.11^{\mathrm{b}}$ \\
\hline & Masuran & $23.92^{\mathrm{de}}$ & $33.69^{c}$ & $8.13^{\text {cdef }}$ & $10.63^{\text {cde }}$ & $2.08^{\mathrm{rs}}$ & $6.84^{\mathrm{d}}$ \\
\hline & Pachchaperumal & $19.55^{\text {efg }}$ & $30.34^{\mathrm{de}}$ & $6.38^{\text {defgh }}$ & $8.20^{\mathrm{hi}}$ & $9.43^{\mathrm{bc}}$ & $11.76^{\mathrm{b}}$ \\
\hline & Rath suwandel & $20.13^{\mathrm{efg}}$ & $30.46^{\mathrm{de}}$ & $6.13^{\text {defgh }}$ & $8.50^{\mathrm{g}}$ & $1.38^{\mathrm{tu}}$ & $5.56^{\mathrm{ef}}$ \\
\hline & Rathel & $30.81^{\mathrm{b}}$ & $-*$ & $9.63^{\text {cde }}$ & $-*$ & $8.08^{\mathrm{cd}}$ & $-*$ \\
\hline & Sulai & $22.78^{\mathrm{def}}$ & $23.04^{\mathrm{gh}}$ & $8.88^{\text {cdef }}$ & $10.63^{\text {cde }}$ & $4.36^{\mathrm{kl}}$ & $7.55^{\mathrm{c}}$ \\
\hline & Thatu vee & $28.92^{\mathrm{bc}}$ & $32.27^{\mathrm{cd}}$ & $7.88^{\text {cdef }}$ & $10.63^{\text {cde }}$ & $3.54^{\mathrm{no}}$ & $6.25^{\mathrm{de}}$ \\
\hline \multirow[t]{15}{*}{ Newly Improved } & At308 & $16.88^{\text {fgh }}$ & $19.67^{\mathrm{hi}}$ & $8.38^{\text {cdef }}$ & $10.00^{\text {cde }}$ & $3.16^{\mathrm{opq}}$ & $19.53^{\mathrm{a}}$ \\
\hline & At309 & $16.26^{\mathrm{fgh}}$ & $19.22^{\mathrm{hi}}$ & $9.19^{\text {cdef }}$ & $7.88^{\text {hij }}$ & $7.22^{\mathrm{e}}$ & $4.17^{\mathrm{j}}$ \\
\hline & At311 & $17.89^{\mathrm{fgh}}$ & $21.69^{\text {ghi }}$ & $7.31^{\text {cdefg }}$ & $7.88^{\text {hij }}$ & $5.05^{\mathrm{j}}$ & $3.55^{\mathrm{k}}$ \\
\hline & At354 & $22.58^{\mathrm{def}}$ & $26.23^{\mathrm{f}}$ & $10.5^{\text {bcd }}$ & $11.13^{\text {bcd }}$ & $11.91^{\mathrm{a}}$ & $7.81^{\mathrm{c}}$ \\
\hline & At373 & $15.22^{\mathrm{fgh}}$ & $18.35^{\mathrm{hi}}$ & $9.25^{\mathrm{cde}}$ & $11.00^{\mathrm{bcd}}$ & $4.46^{\mathrm{kl}}$ & $5.56^{\mathrm{ef}}$ \\
\hline & $\mathrm{Bg} 310$ & $16.69^{\mathrm{fgh}}$ & $20.48^{\mathrm{hi}}$ & $8.75^{\text {cdef }}$ & $10.38^{\text {cde }}$ & $0.84^{\mathrm{uv}}$ & $11.22^{\mathrm{b}}$ \\
\hline & $\mathrm{Bg} 359$ & $23.60^{\text {def }}$ & $19.84^{\mathrm{hi}}$ & $8.93^{\text {cdef }}$ & $10.13^{\text {cde }}$ & $5.35^{\mathrm{ij}}$ & $5.21^{\mathrm{gh}}$ \\
\hline & $\mathrm{Bg} 366$ & $22.71^{\mathrm{def}}$ & $26.23^{\mathrm{f}}$ & $11.31^{\mathrm{bc}}$ & $13.25^{\mathrm{ab}}$ & $4.22^{\mathrm{lm}}$ & $4.81^{\text {ghi }}$ \\
\hline & Bg369 & $22.26^{\mathrm{def}}$ & $26.68^{\mathrm{f}}$ & $8.50^{\text {cdef }}$ & $10.13^{\text {cde }}$ & $9.26^{\mathrm{bc}}$ & $7.81^{\mathrm{c}}$ \\
\hline & Bw363 & $17.58^{\text {fgh }}$ & $33.11^{\mathrm{cd}}$ & $5.86^{\text {defgh }}$ & $7.50^{\text {hij }}$ & $0.92^{\mathrm{uv}}$ & $4.17^{\mathrm{j}}$ \\
\hline & Bw367 & $17.99^{\mathrm{fgh}}$ & $21.94^{\text {ghi }}$ & $13.00^{\mathrm{a}}$ & $13.63^{\mathrm{ab}}$ & $3.54^{\mathrm{no}}$ & $5.85^{\mathrm{ef}}$ \\
\hline & Bw452 & $17.58^{\mathrm{fgh}}$ & $20.59^{\mathrm{hi}}$ & $8.63^{\text {cdef }}$ & $12.00^{\mathrm{bc}}$ & $1.79^{\mathrm{st}}$ & $-* *$ \\
\hline & $\mathrm{Ld} 356$ & $21.94^{\mathrm{def}}$ & $31.62^{\mathrm{cd}}$ & $8.06^{\text {cdef }}$ & $10.00^{\text {cde }}$ & $1.05^{\mathrm{uv}}$ & $5.21 \mathrm{gh}$ \\
\hline & $\operatorname{Ld} 365$ & $19.16^{\mathrm{efg}}$ & $19.95^{\mathrm{hi}}$ & $9.44^{\text {cde }}$ & $11.63^{\mathrm{bcd}}$ & $9.70^{\mathrm{bc}}$ & $4.17^{\mathrm{j}}$ \\
\hline & $\operatorname{Ld} 371$ & $22.32^{\text {def }}$ & $33.69^{\mathrm{cd}}$ & $7.25^{\text {defgh }}$ & $7.63^{\text {hij }}$ & $1.70^{\mathrm{st}}$ & $4.17^{\mathrm{j}}$ \\
\hline \multirow[t]{3}{*}{ Old Improved } & $\mathrm{H}-10$ & $22.78^{\text {def }}$ & $31.53^{\mathrm{cd}}$ & $7.56^{\text {cdef }}$ & $9.75^{\text {def }}$ & $6.06^{\text {fgh }}$ & $6.51^{\mathrm{de}}$ \\
\hline & $\mathrm{H}-4$ & $26.68^{\mathrm{cd}}$ & $30.90^{\text {de }}$ & $10.44^{\mathrm{bcd}}$ & $10.50^{\text {cde }}$ & $6.26^{\mathrm{fg}}$ & $6.25^{\mathrm{de}}$ \\
\hline & $\mathrm{H}-7$ & $22.39^{\text {def }}$ & $32.92^{\mathrm{cd}}$ & $5.50^{\text {efgh }}$ & $7.50^{\text {hij }}$ & $3.34^{\mathrm{op}}$ & $5.21^{\mathrm{gh}}$ \\
\hline
\end{tabular}

* Data were not collected as these landraces did not flower in Yala season.

** Unable to collect data since the seeds were exposed to birds, pests and diseases.

Means denoted by same letters within each column are not significantly different at $\mathrm{p}<0.05$. 
The highest FLL was reported for Kuruluthudu in Maha season and Herath banda in Yala season; however, the widest flag leaf was observed in BW367 in both Yala and Maha seasons. Significantly higher yields were reported by newly improved cultivars under Yala and Maha seasons where AT354 reported $11.91 \mathrm{~g}$ per plant in Yala season and AT306 reported $19.53 \mathrm{~g}$ per plant in Maha season (Table 5). Similar to PLH; FLL and the FLW followed the varietal specific pattern and seem to be less affected by PD conditions (Table 5).

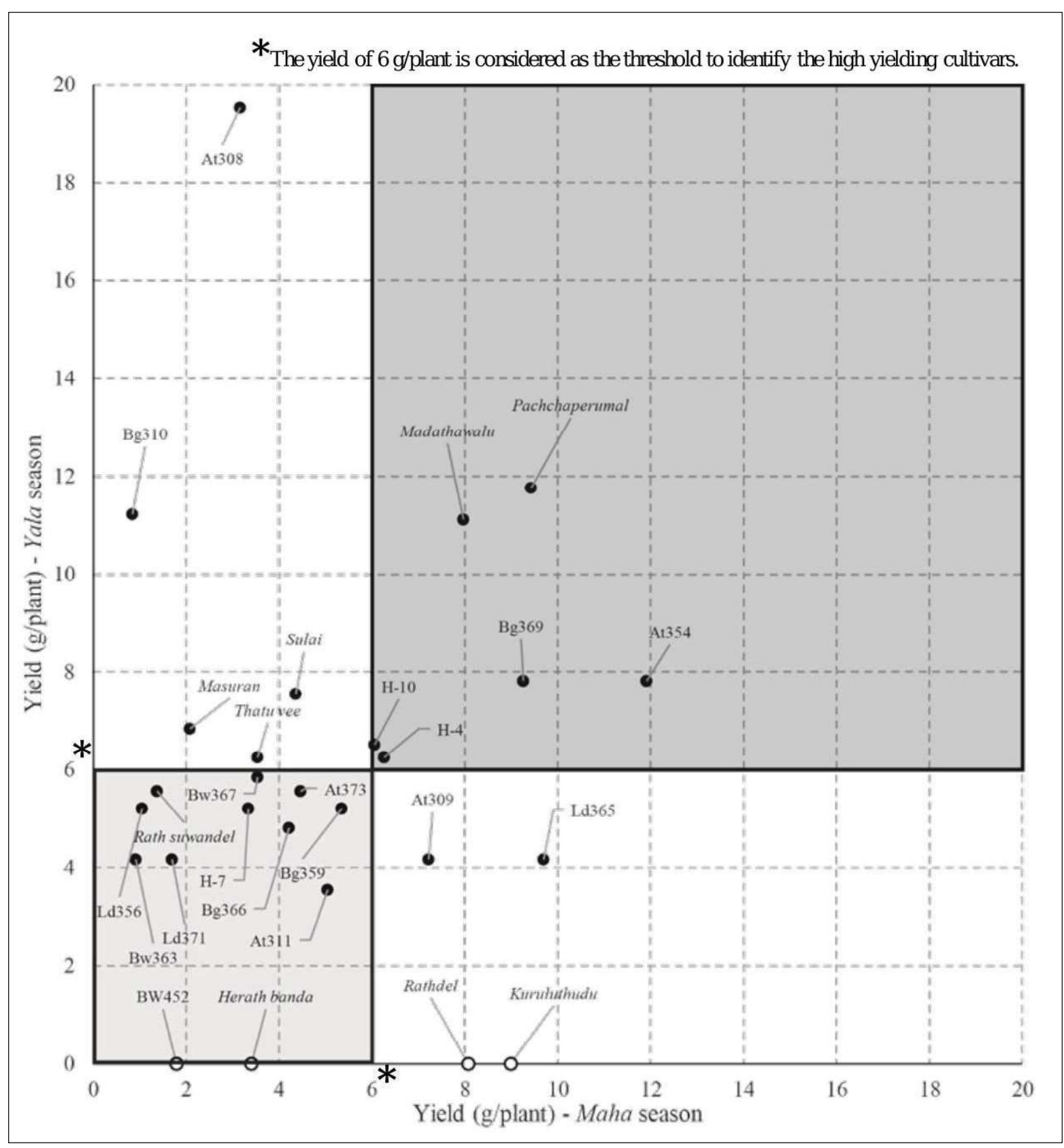

Figure 1: The scatter plot drawn between the mean yield of the cultivars assessed in Maha and Yala seasons. Six grams per plant is considered as the threshold for identifying the high yielding cultivars under P starved conditions. Dark gray area represents the high yielding cultivars in both seasons and light gray area represent the low yielding cultivars in both seasons (For BW452, Herath banda, Rathdel and Kuruluthudu, data were only available in Maha season). 
The yield per plant is an ideal trait to identify $\mathrm{P}$ deficiency tolerant cultivars under P starved conditions. The grand mean of the yield reported for a cultivar in both seasons was six grams per plant. When this yield level was considered as the expected threshold to declare the $\mathrm{P}$ deficiency tolerant cultivars, Pachchaperumal, Madathavalu, Bg369, AT354, H-10 and H-4 provided higher yield than six grams per plant, thereby can be considered as promising cultivars providing the above average yield under $\mathrm{P}$ starved conditions (Figure 1). A total of one OI, one landrace and seven NI provided a mean yield of less than six grams per plant in both seasons, showing the negative effect of $\mathrm{P}$ limitation on the yield (Table 5; Figure 1). The yield under $\mathrm{P}$ limited conditions is especially important as a selection parameter in breeding and screening. However, only six cultivars were identified as providing above average yield under P sparse conditions.

Table 6: Variation of phosphorus deficiency tolerance (PDT) indicators under P starved field condition

\begin{tabular}{|c|c|c|c|c|c|c|c|c|c|}
\hline \multirow[t]{2}{*}{ Type } & \multirow[t]{2}{*}{ Cultivar } & \multicolumn{2}{|c|}{ SDW (g/plant) } & \multicolumn{2}{|c|}{$\mathrm{SPC}(\mathrm{mg} / \mathrm{g})$} & \multicolumn{2}{|c|}{ SPU (mg/plant) } & \multicolumn{2}{|c|}{ PUE (g/mg) } \\
\hline & & Maha & Yala & Maha & Yala & Maha & Yala & Maha & Yala \\
\hline \multirow[t]{9}{*}{ Landrace } & Herath banda & $3.34 \mathrm{efg}$ & $29.17^{\mathrm{a}}$ & $1.61 \mathrm{ab}$ & 1.49 bcde & $5.37 \mathrm{ab}$ & $41.69^{\mathrm{a}}$ & $0.62^{a b}$ & 0.67 bcdef \\
\hline & Kuruluthudu & $16.78^{a}$ & $-*$ & $1.12^{\mathrm{b}}$ & $-*$ & $18.62^{a b}$ & $-*$ & $0.89^{a b}$ & $-*$ \\
\hline & Madathawalu & $15.66^{\mathrm{a}}$ & $14.13^{\mathrm{bcd}}$ & $2.02^{a b}$ & $1.48^{\text {bcde }}$ & $30.90^{\mathrm{ab}}$ & $20.65^{\mathrm{abcd}}$ & $0.50^{\mathrm{b}}$ & $0.68^{\text {bcdef }}$ \\
\hline & Masuran & $7.16^{\text {abcdef }}$ & $6.76^{\text {hijk }}$ & $1.42^{a b}$ & $1.38^{\text {bcde }}$ & $10.47^{a b}$ & $22.91 \mathrm{abc}$ & $0.71^{\mathrm{ab}}$ & 0.72 bcdef \\
\hline & Pachchaperumal & $3.84^{\mathrm{cdefg}}$ & $5.89^{\mathrm{ijkl}}$ & $0.59^{\mathrm{b}}$ & 1.73 abcd & $2.29^{b}$ & $10.00^{\text {cdefghi }}$ & $1.69^{\mathrm{a}}$ & 0.58 cdef \\
\hline & Rathdel & $15.66^{\mathrm{a}}$ & $-*$ & $2.10^{\mathrm{ab}}$ & $-*$ & $35.48^{a}$ & $-*$ & $0.48^{b}$ & $-*$ \\
\hline & Rath suwandel & $2.88^{\mathrm{fg}}$ & $3.85^{1}$ & $0.93^{\mathrm{b}}$ & $1.12^{\text {cde }}$ & $2.66^{\mathrm{ab}}$ & $9.77^{\text {cdefghi }}$ & $1.07^{\mathrm{ab}}$ & 0.89 bcde \\
\hline & Sulai & $6.76^{\text {abcdefg }}$ & $7.08^{\text {ghijk }}$ & $1.64^{\mathrm{a} b}$ & 0.88 de & $11.22^{\mathrm{ab}}$ & $10.35^{\text {cdefghi }}$ & $0.61^{\mathrm{ab}}$ & 1.14 bed \\
\hline & Thatuvee & $6.45^{\text {abcdefg }}$ & $9.12^{\text {defghi }}$ & $0.86^{b}$ & 0.89 de & $5.31^{\mathrm{ab}}$ & 14.29 bcdef & $1.16^{\mathrm{ab}}$ & $1.13^{b c}$ \\
\hline \multirow[t]{15}{*}{ Newly Improved } & At308 & $3.54^{\text {defg }}$ & $4.17^{1}$ & $1.10^{\mathrm{a}}$ & $1.83^{\mathrm{abcd}}$ & $12.59^{a b}$ & 7.59 efghi & $0.91^{\mathrm{b}}$ & $0.55^{\text {def }}$ \\
\hline & At309 & 4.73 bcdefg & $5.62^{\mathrm{jkl}}$ & $1.40^{\mathrm{ab}}$ & 1.32 bcde & $6.68^{\mathrm{ab}}$ & 7.50 efghi & $0.71^{\mathrm{ab}}$ & $0.76^{\text {bcdef }}$ \\
\hline & At311 & $11.61^{\mathrm{ab}}$ & $12.88^{\text {cde }}$ & $2.34^{\mathrm{ab}}$ & 1.41 bcde & $26.61^{\mathrm{ab}}$ & $5.43^{\text {hi }}$ & $0.43^{\mathrm{b}}$ & 0.71 bcdef \\
\hline & At354 & 7.49 abcdef & $10.47^{\text {defgh }}$ & $2.19^{\mathrm{ab}}$ & 1.81 abcd & $16.22^{a b}$ & $15.85^{\text {bcdef }}$ & $0.46^{\mathrm{b}}$ & 0.55 def \\
\hline & At373 & $8.81^{\text {abcde }}$ & $8.71^{\text {efghij }}$ & $1.69^{\mathrm{ab}}$ & $1.74^{\mathrm{abcd}}$ & $14.45^{\mathrm{ab}}$ & $18.20^{\text {abcde }}$ & $0.59^{\mathrm{ab}}$ & $0.57^{\mathrm{cdef}}$ \\
\hline & $\mathrm{Bg} 310$ & $2.37^{\mathrm{g}}$ & $4.17^{1}$ & $1.04^{b}$ & $1.73^{\mathrm{abcd}}$ & $2.34^{\mathrm{b}}$ & $7.16^{\text {fghi }}$ & $0.96^{\mathrm{ab}}$ & 0.58 cdef \\
\hline & Bg359 & 4.73 bcdefg & 8.32 efghij & $2.72^{a b}$ & $0.84^{\text {de }}$ & $12.88^{a b}$ & 6.84 fghi & $0.37^{\mathrm{b}}$ & $1.20^{\mathrm{b}}$ \\
\hline & Bg366 & 8.03 abcdef & $7.85^{\text {fghijk }}$ & $1.70^{\mathrm{ab}}$ & 1.74 abcd & $13.49^{a b}$ & $13.65^{\text {bcdefg }}$ & $0.59^{\mathrm{ab}}$ & $0.57^{\mathrm{cdef}}$ \\
\hline & $\operatorname{Bg} 369$ & $5.12^{\text {bcdefg }}$ & $6.10^{\mathrm{ijkl}}$ & $1.10^{\mathrm{b}}$ & 0.92 de & $5.43^{\mathrm{ab}}$ & 5.62 ghi & $0.91^{\mathrm{ab}}$ & 1.09 bcde \\
\hline & Bw363 & $4.78^{\text {bcdefg }}$ & $7.00^{\text {ghijk }}$ & $1.31^{\mathrm{ab}}$ & $1.81^{\mathrm{abcd}}$ & $5.96^{\mathrm{ab}}$ & 12.59 bcdefgh & $0.76^{\mathrm{ab}}$ & $0.55^{\text {def }}$ \\
\hline & Bw367 & $11.22^{a b c}$ & $11.48^{\text {cdef }}$ & $1.99^{a b}$ & 1.44 bcde & $22.13^{\mathrm{ab}}$ & 8.32 defghi & $0.50^{\mathrm{b}}$ & $0.70^{\text {bcdef }}$ \\
\hline & Bw452 & $5.68^{\text {abcdefg }}$ & $5.19^{\mathrm{kl}}$ & $1.78^{a b}$ & $2.12^{a b c}$ & $10.00^{\mathrm{ab}}$ & $15.85^{\text {bcdef }}$ & $0.56^{\mathrm{ab}}$ & $0.47^{\text {ef }}$ \\
\hline & Ld356 & 7.07 abcdef & $10.47^{\text {defgh }}$ & $1.22^{b}$ & 0.92 de & $8.04^{\mathrm{ab}}$ & $4.95^{\mathrm{i}}$ & $0.82^{\mathrm{ab}}$ & 1.09 bcde \\
\hline & $\operatorname{Ld} 365$ & $8.31^{\text {abcdef }}$ & $10.72^{\text {defgh }}$ & $1.60^{\mathrm{ab}}$ & $2.60^{\mathrm{a}}$ & $16.41^{\mathrm{ab}}$ & $27.23^{\mathrm{ab}}$ & $0.62^{a b}$ & $0.39^{\mathrm{f}}$ \\
\hline & Ld371 & $6.60^{\text {abcdefg }}$ & $10.00^{\text {defgh }}$ & $1.31^{\mathrm{ab}}$ & $0.99^{\text {de }}$ & $8.71^{\mathrm{ab}}$ & $10.23^{\text {cdefghi }}$ & $0.76^{\mathrm{ab}}$ & $1.02^{\text {bcde }}$ \\
\hline \multirow[t]{3}{*}{ Old Imrpoved } & H-10 & $10.83^{a b c}$ & $17.18^{\mathrm{bc}}$ & $1.84^{\mathrm{ab}}$ & $2.17^{\mathrm{ab}}$ & $19.28^{a b}$ & $22.91 \mathrm{abc}$ & $0.54^{\mathrm{ab}}$ & $0.46^{\mathrm{f}}$ \\
\hline & $\mathrm{H}-4$ & $10.47^{\mathrm{abcd}}$ & $20.18^{\mathrm{ab}}$ & $1.55^{\mathrm{ab}}$ & $1.09^{\mathrm{de}}$ & $16.22^{a b}$ & $21.88^{a b c}$ & $0.65^{\mathrm{ab}}$ & 0.92 bcdef \\
\hline & $\mathrm{H}-7$ & $6.16^{\text {abcdefg }}$ & $8.41^{\text {efghij }}$ & $1.61^{\mathrm{ab}}$ & $0.52^{\mathrm{e}}$ & $9.89^{\mathrm{ab}}$ & $4.37^{\mathrm{i}}$ & $0.62^{\mathrm{ab}}$ & $1.92^{\mathrm{a}}$ \\
\hline
\end{tabular}

* Data were not collected from these landraces as they did not flower in Yala season.

SDW: shoot dry weight; SPC: shoot P concentration; SPU: shoot P uptake; PUE: P utilization efficiency.

Means denoted by same letters within each column are not significantly different at $\mathrm{p}<0.05$. 

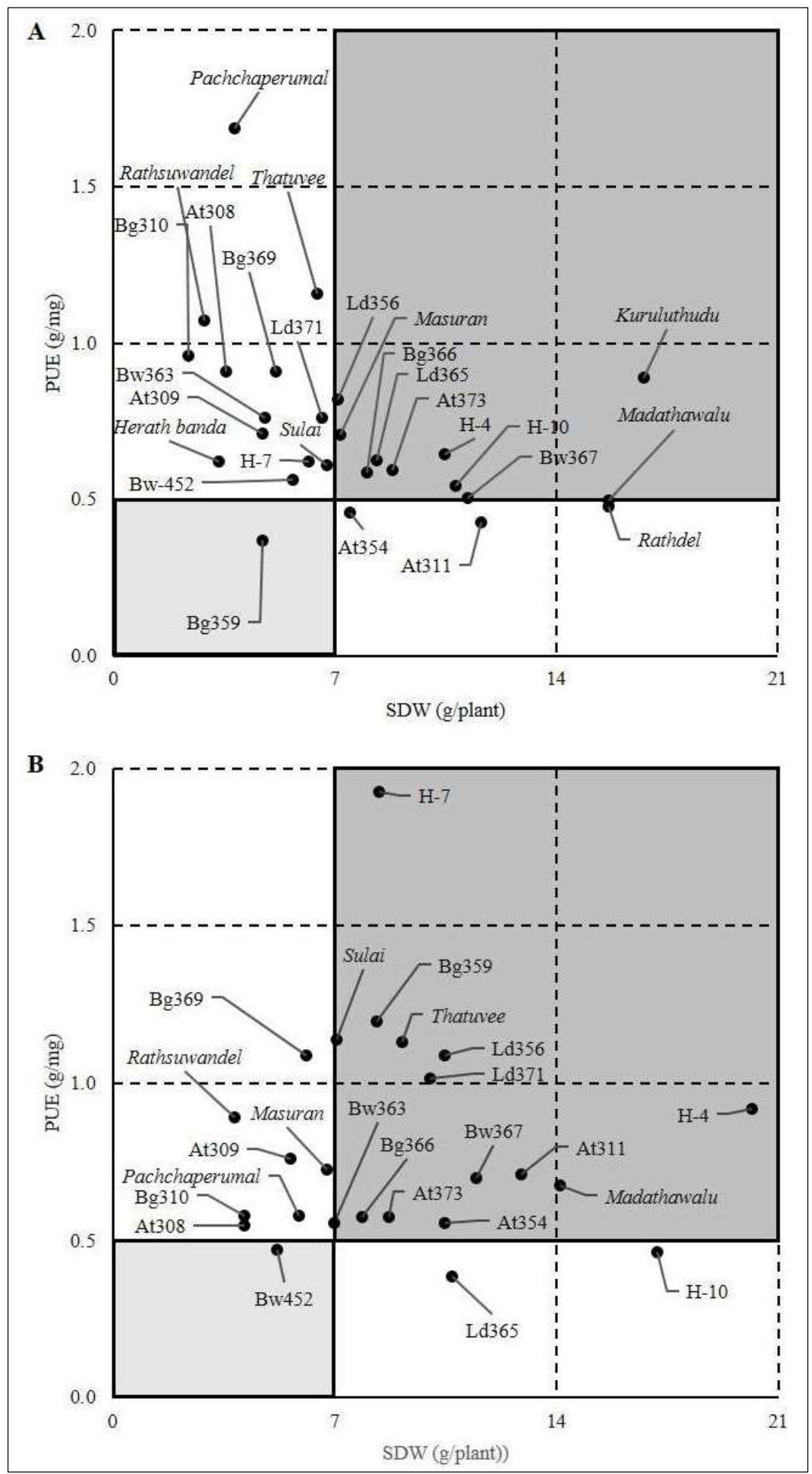

Figure 2: The scatter plot drawn between shoot dry weight (SDW) and p utilisation efficiency (PUE) of the rice cultivars in A: Maha season; B: Yala season. Two threshold lines are drawn at $7 \mathrm{~g} / \mathrm{plant}$ of SDW and $0.5 \mathrm{~g} / \mathrm{mg}$ of PUE. The P deficiency tolerant cultivars are indicated in dark gray box and the PD sensitive cultivars are indicated in light gray box. 


\section{Variation on the PDT indicators}

The significantly higher SDW was identified in Rathdel in Maha season and Herath banda in Yala season. However, under the Duncan's grouping of means, many other cultivars also showed significantly higher mean SDW values with overlapping groups (Table 6). The variation of SPC, SPU and PUE indicated that the studied rice cultivars are variable and mostly seasonal-specific in responding to $\mathrm{P}$ limited soil conditions. The inverse values of SPC is defined as PUE. Higher SPC or SPU means that the plants accumulate a higher amount of $\mathrm{P}$ without partitioning into required tissues. Therefore, the relationship between SDW (amount of biomass generated under $\mathrm{P}$ limited conditions in the context of present study) and PUE would provide the basis to identify PDT of the rice cultivars. As given in previous studies, $7 \mathrm{~g}$ of SDW per plant and $0.5 \mathrm{~g} / \mathrm{mg}$ of PUE were used as the two thresholds (i.e., independent culling levels) (Vandamme et al., 2016; Chankaew et al., 2019) to identify the $\mathrm{P}$ deficiency tolerant and $\mathrm{P}$ deficiency sensitive cultivars (Figure 2).

In the Maha season, Kuruluthudu, Madathawalu, Masuran, and seven improved cultivars showed SDW and PUE above the thresholds indicating that they were PD tolerant. Similarly, in Yala season, Madathawalu, Thatuvee, Sulai, and ten improved cultivars were PD tolerant. The landrace Madathawalu, OI cultivar H-4 and NI cultivars Bg366, Ld359, At373, Bw367 and Bg366 were PD tolerant in both seasons (Figures 2A and 2B). Bg359 in Maha season, and Bw452 in Yala season were found to be PD sensitive. Other cultivars got moved back and forth in two moderately $\mathrm{P}$ deficiency tolerant classes (PUE $>0.5 \mathrm{~g} / \mathrm{mg}, \mathrm{SDW}<7 \mathrm{~g}$ or $\mathrm{PUE}<0.5 \mathrm{~g} / \mathrm{mg}$ and SWD $>7 \mathrm{~g}$ ) in Maha and Yala seasons (Figures 2A and 2B).

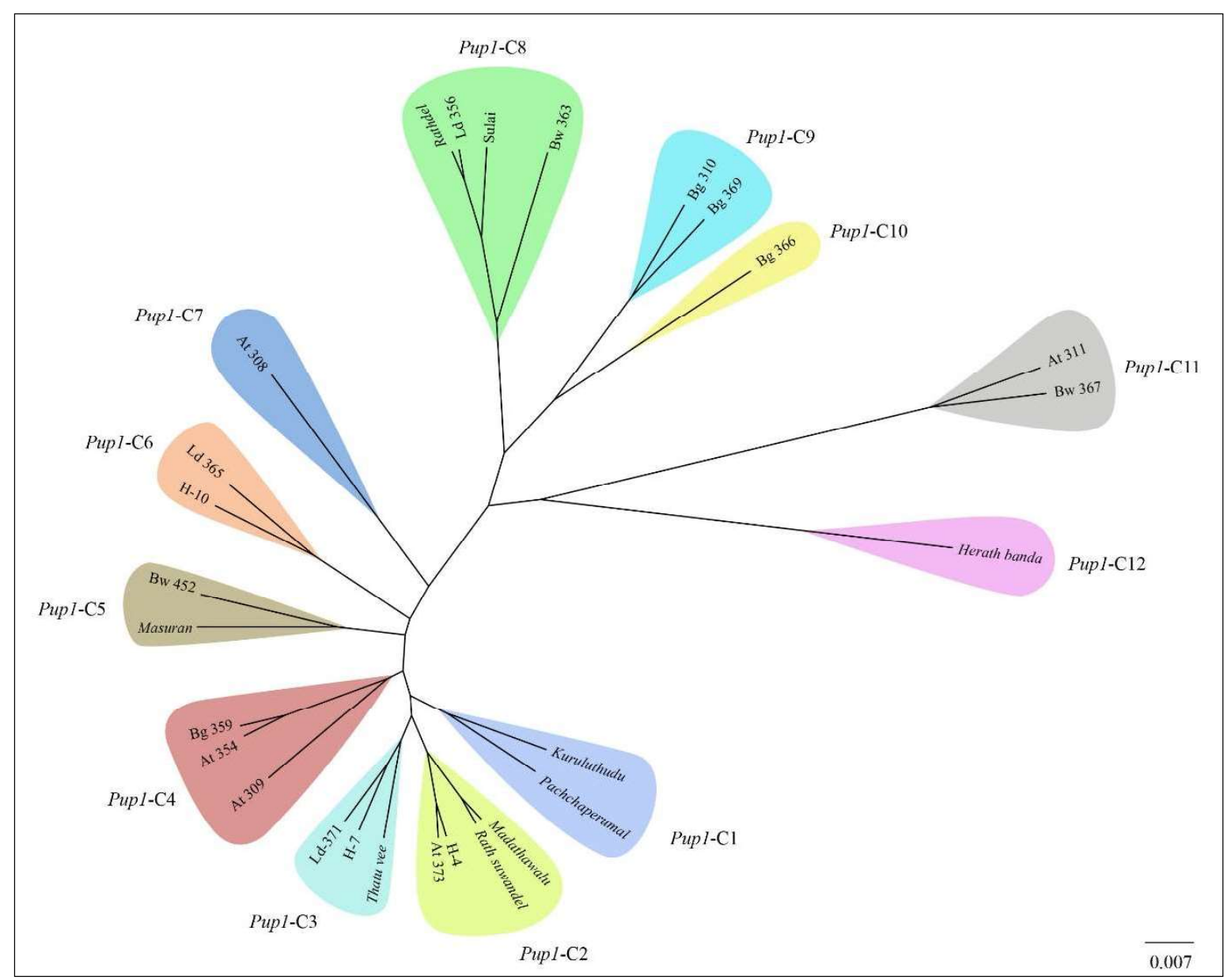

Figure 3: The clustergram constructed for the 27 rice cultivars based on the Pupl linked marker haplotypes. The dissimilarity matrix was constructed using the unweighted pair group method with arithmetic means (UPGMA) (Nei \& Kumar, 2000). 
Many studies reported that both SDW and PUE must be considered to identify the level of PDT of a given rice cultivar (Wissuwa et al., 1998; Aluwihare et al., 2016). The breeders must target for higher levels of SDW and PUE in developing improved rice varieties. In the present study, P deficiency tolerant cultivars for Maha, and Yala seasons (Figure 2A and 2B) were identified. The results are in line with the results presented by Aluwihare et al. (2016) as both studies identified H-4 as PDT.

SDW is an ideal parameter for selection because it expresses the amount of biomass produced under $\mathrm{P}$ sparse conditions, and PUE is also ideal as it reflects the partitioning of $\mathrm{P}$ into sink tissues under low $\mathrm{P}$ conditions. However, it is important to select simultaneously based on the yield and PDT indicators for more robust screening outcomes (Wissua \& Ae, 2001; Fageria \& Santos, 2002; Fageria \& Knupp, 2013). In both Maha and Yala seasons, if yield and PDT indicators are considered simultaneously, H-4 and Madathawalu can be considered as the stable P deficiency tolerant rice cultivars (Figures 1 and 2).

\section{Diversity of Pup 1 linked DNA marker haplotypes}

The UPGMA cluster analysis generated 12 clusters (Pup1-C1 to Pup1-C12 in Figure 3). Cluster Pup 1-C1 only contains two Sri Lankan landraces, which are moderately tolerant or tolerant to P deficiency. Pup1-C2 contains two $\mathrm{P}$ deficiency tolerant rice cultivars, Madathawalu and H-4 and the rest of the two are moderately tolerant cultivars (At 373 and Rath Suwandel). Cluster Pupl-C3 contains

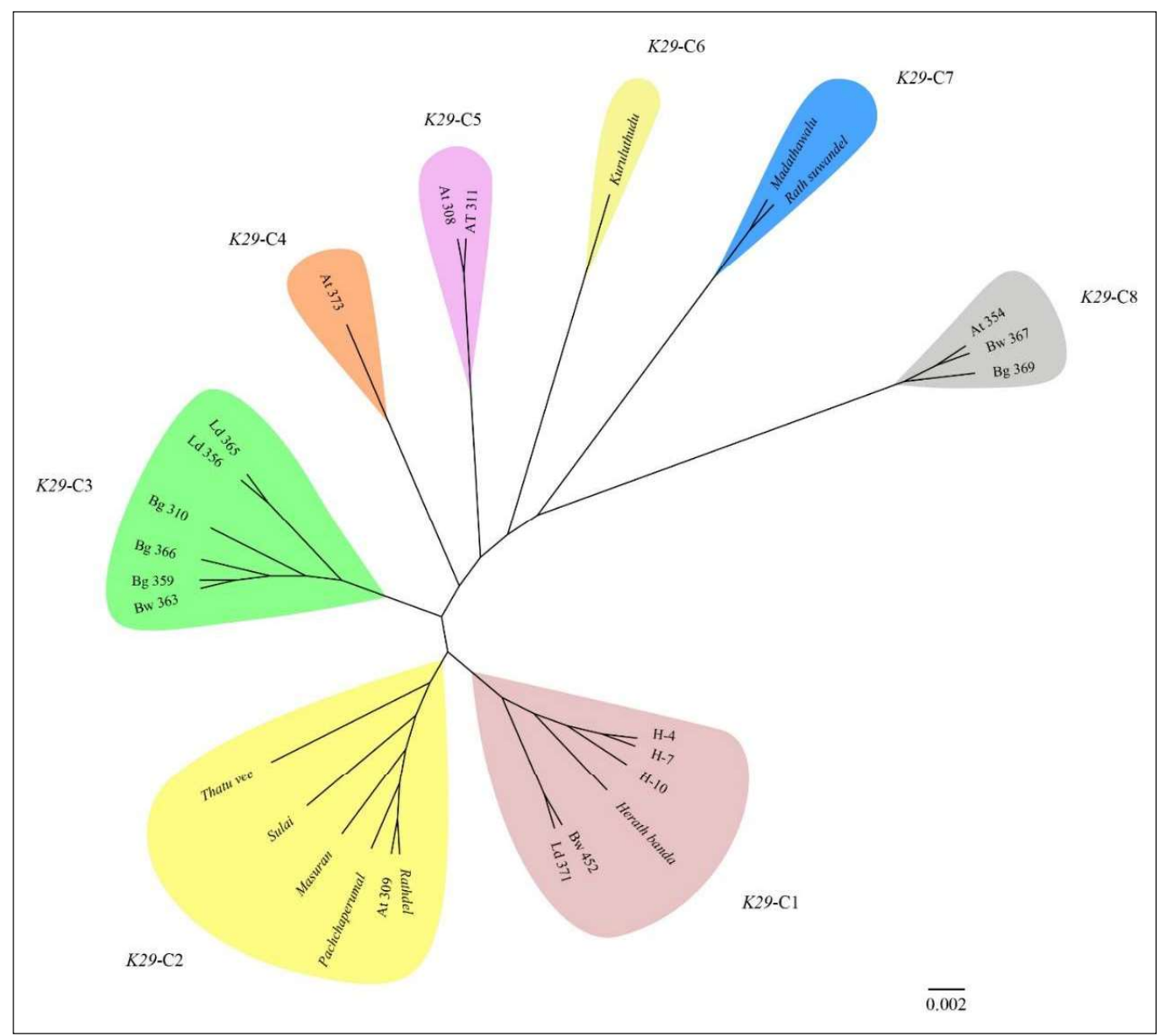

Figure 4: The clustergram constructed for rice cultivars based on the sequence polymorphism at $K 29$ locus. The cluster labels are indicated at each cluster. 
only moderately tolerant rice genotype. Within Pup1-C4 moderately tolerant $\mathrm{Bg} 359$ and At354 grouped distantly from the sensitive cultivar At309. Pup1-C11 contains the most genetically distinct $\mathrm{P}$ deficiency tolerant genotypes (At311 and Bw367). Within the Pup1-C8, Bw363 which is a PD sensitive cultivar showed a clear genetic distance from the rest of the cultivars within the cluster (Figure 3).

\section{$K 29$ and $R M 28102$ based sequence diversity}

The sequence polymorphism at $K 29$ locus generated eight clusters; K29-C1 contains the P deficiency tolerant cultivar H-4. However, the overall clustering structure does not coincide with the PDT variation shown in Figure 2 for Maha and Yala seasons (Figure 4). The sequence polymorphism at $R M 28102$ generated eight clusters and a big paraphyletic group in RM28102-C1 (Figure 5). There, Madathawalu and Rath suwadal are apparent as unique haplotypes. However, the overall clustering structure is not correlated with PDT diversity structure shown in Figure 2.
The haplotype analysis at Pupl QTL for rice cultivars and the sequence polymorphism-based diversity analysis for two linked markers revealed variable diversity structures. This kind of higher diversity within Pupl QTL is reported in many studies (Heuer et al., 2009; Chin et al., 2010; 2011) and has also been linked to the very high transposon activity going on near and within Pup1 QTL (Heuer et al., 2009). The haplotype and sequence diversity observed in the present study also proved that the rice germplasm in Sri Lanka is very highly diverse at this locus (Aluwihare et al. 2016) and implied the possibility of mining novel haplotypes for PDT. For MAB of rice for PDT, it is interesting to note that the stable $\mathrm{P}$ deficiency tolerant H-4 and Madathawalu (as indicated by yield and PDT indicators) are positioned within the Pup1-C2 cluster. Aluwihare et al. (2016) reported that H-4 bears a different Pup1 QTL haplotype to Kasalath. The tolerant haplotype in H-4 was inherited from one of its parents, Murungakayan, another P deficiency tolerant landrace in Sri Lanka (Aluwihare et al., 2016). Therefore, it is logical to assume that Madathaawalu also shares

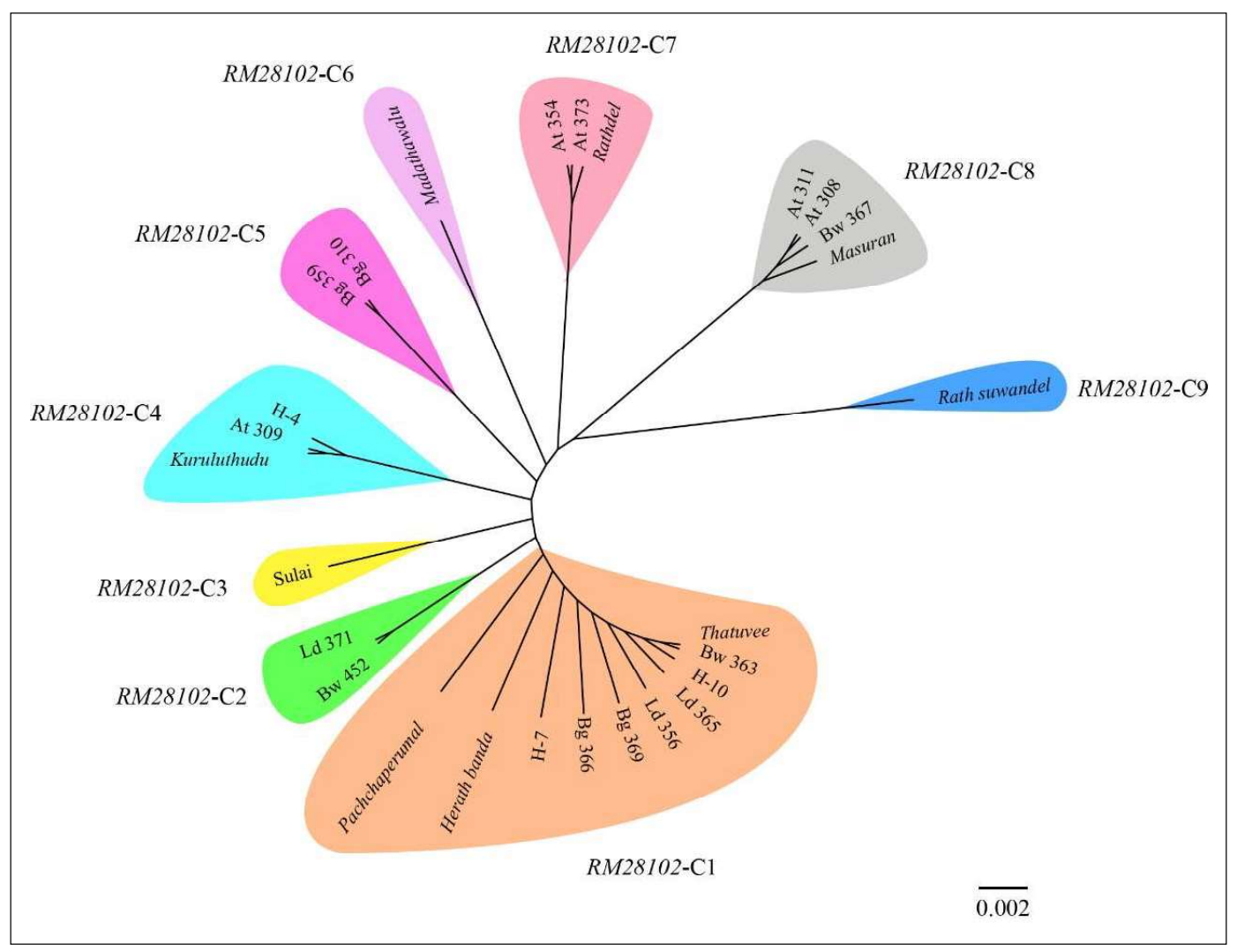

Figure 5: The cluster diagram constructed for rice cultivars based on the sequence polymorphism at $R M 28102$ locus. The cluster labels are indicated at each cluster. 
the same haplotype as in H-4 and Murungakayan. The present study thereby proves the utmost importance of screening locally available landraces and cultivars and subsequent correlation with Pupl haplotype to lay a platform for MAB of rice (Chin et al., 2010; Aluwihare et al., 2017; 2018).

\section{CONCLUSIONS}

The present study identified that the rice cultivars Kuruluthudu, Madathawalu, Masuran, At373, Bg366, Bw367, H-4, H-10, Ld356, and Ld365 are phosphorus deficiency tolerant in Maha season while Madathawalu, Sulai, Thatuvee, At-311, At354, At373, Bg359, Bg366, Bw363, Bw367, H-4, H-7, Ld356, and Ld371 are phosphorus deficiency tolerant in Yala season. The landrace Madathawalu and old improved variety $\mathrm{H}-4$ are phosphorus deficiency tolerant and provided significantly higher yield performance in both Maha and Yala seasons. Also, Madathawalu and H-4 got clustered together in Pupl linked DNA marker-based haplotype analysis. Thus, Madathawalu and H-4 can be used as breeding parents in marker assisted breeding programmes to introgress phosphorus deficiency tolerance to new rice varieties. Madathawalu is one of the frequently grown landraces in organic rice farming in Sri Lanka. According to the phosphorus deficiency screening results of the present study, Madathawalu can be recommended as a promising landrace to grow under zero or minimum phosphorus fertiliser-application regimes.

\section{REFERENCES}

Aluwihare Y.C., Chamikara M.D.M., Dissanayake D.R.R.P., Dissanayake M.D.M.I.M., Karannagoda N.N.H., Dayananda A.G.M.L.K., Sirisena D.N., Samarasinghe W.L.G., Rajapakse R.G.S.C. \& Sooriyapathirana S.D.S.S. (2017). DNA sequence polymorphism of Pupl linked K201 STS region can be effectively used in molecular breeding of rice for phosphorus deficiency tolerance. Journal of the National Science Foundation of Sri Lanka 45(4): 413-425. DOI: http://doi.org/10.4038/jnsfsr.v45i4.8235

Aluwihare Y.C., Chamikara M.D.M., Dissanayake D.R.R.P., Karunarathne S.I., Ananda G.K.S., Kannangara S.K., Madhukalpani O.V.S., Sirisena D.N., Samarasinghe W.L.G. \& Sooriyapathirana S.D.S.S. (2018). Identification of Pup1 QTL linked DNA marker haplotypes for molecular breeding of phosphorous deficiency tolerant rice varieties. Journal of the National Science Foundation of Sri Lanka 46(4): 495-504.

DOI: http://dx.doi.org/10.4038/jnsfsr.v46i4.8625

Aluwihare Y.C., Ishan M., Chamikara M.D.M., Weebadde C.K., Sirisena D.N., Samarasinghe W.L.G. \& Sooriyapathirana
S.D.S.S. (2016). Characterization and selection of phosphorus deficiency tolerant rice genotypes in Sri Lanka. Rice Science 23(4): 184-195.

DOI: https://doi.org/10.1016/j.rsci.2015.10.001

Bulluck III L.R. \& Ristaino J.B. (2002). Effect of synthetic and organic soil fertility amendments on southern blight, soil microbial communities, and yield of processing tomatoes. Phytopathology 92(2): 181-189.

DOI: https://doi.org/10.1094/PHYTO.2002.92.2.181

Chankaew S., Monkham T., Pinta W., Sanitchon J., Kaewpradit W. \& Srinives P. (2019). Screening tolerance to phosphorus deficiency and validation of phosphorus uptake 1 (Pupl) gene-linked markers in Thai indigenous upland rice germplasm. Agronomy 9(2): 81.

DOI: https://doi.org/10.3390/agronomy9020081

Chin J.H., Gamuyao R., Dalid C., Bustamam M., Prasetiyono J., Moeljopawiro S., Wissuwa M. \& Heuer S. (2011). Developing rice with high yield under phosphorus deficiency: Pup1 sequence to application. Plant physiology 156(3): 1202-1216.

DOI: https://doi.org/10.1104/pp.111.175471

Chin J.H., Lu X., Haefele S.M., Gamuyao R., Ismail A., Wissuwa M. \& Heuer S. (2010). Development and application of gene-based markers for the major rice QTL phosphorus uptake 1. Theoretical and Applied Genetics 120: $1073-1086$.

DOI: https://doi.org/10.1007/s00122-009-1235-7

Cordell D., Drangert J.O. \& White S. (2009). The story of phosphorus: global food security and food for thought. Global Environmental Change 19: 292-305.

DOI: https://doi.org/10.1016/j.gloenvcha.2008.10.009

Department of Agriculture, Sri Lanka (DOA) (2006). Climate of rice growing regions in Sri Lanka. Available at http:// www.agridept.gov.lk/. Accessed 10 July 2020.

Fageria N.K. \& Knupp A.M. (2013). Upland rice phenology and nutrient uptake in tropical climate. Journal of Plant Nutrition 36: 1-14.

DOI: https://doi.org/10.1080/01904167.2012.724136

Fageria N.K. \& Santos B. (2002). Lowland rice genotypes evaluation for phosphorus use efficiency. Journal of Plant Nutrition 25 (12): 2793-2802.

DOI: https://doi.org/10.1081/PLN-120015539

Fageria N.K., Wright R.J. \& Baligar V.C. (1988). Rice cultivar evaluation for phosphorus use efficiency. Plant and Soil Science 111: 105-109.

DOI: https://doi.org/10.1007/BF02182043

Felsenstein J. (2005). PHYLIP (Phylogeny Inference Package) version 3.6. Department of Genome Sciences, University of Washington. Available at https://evolution.genetics. washington.edu/phylip.html. Accessed 10 July 2020.

Food and Agriculture Organization of the United Nations (FAO) (2015). Rice market monitor 18(2): 1-10.

Gunes A., Inal A., Alpaslan M. \& Cakmak I. (2006). Genotypic variation in phosphorus efficiency between wheat cultivars grown under greenhouse and field conditions. Soil Science and Plant Nutrition 52: 470-478.

DOI: https://doi.org/10.1111/j.1747-0765.2006.00068.x 
Halford I.C.R. (1997). Soil phosphorus: its measurement, and its uptake by plants. Australian Journal of Soil Research 35: 39-227.

DOI: https://doi.org/10.1071/S96047

Hanson W.C. (1950). The photometric determination of phosphorus in fertilizers using the phosphovanadomolybdate complex. Journal of the Science Food and Agriculture 1: 172-173.

DOI: https://doi.org/10.1002/jsfa.2740010604

Herath H., Hardaker J.B. \& Anderson J.R. (1982). Choice of varieties by Sri Lanka rice farmers: Comparing alternative decision models. American Journal of Agricultural Economics 64: 87-93. DOI: https://doi.org/10.2307/1241176

Heuer S. et al. (11 authors) (2009). Comparative sequence analyses of the major quantitative trait locus phosphorus uptake 1 (Pup1) reveal a complex genetic structure. Plant Biotechnology Journal 7: 456-471. DOI: https://doi.org/10.1111/j.1467-7652.2009.00415.x

Kumar S., Stecher G. \& Tamura K. (2016). MEGA7: molecular evolutionary genetics analysis version 7.0 for bigger datasets. Molecular Biology and Evolution 33(7): 1870 1874.

DOI: https://doi.org/10.1093/molbev/msw054

Kumaragamage D. \& Indraratne S. (2011). Systemic approach to diagnosing fertility problems in soils of Sri Lanka. Communication in Soil Science and Plant Analysis 42(22): 2699-2715.

DOI: https://doi.org/10.1080/00103624.2011.622818

Majumder N., Borthakur D. \& Rakshit S. (1989). Heterosis in rice under phosphorus stress. The Indian Journal of Genetics and Plant Breeding 49(2): 231-235.

Nei M. \& Kumar S. (2000). Phylogenetic inference: Distance methods. In: Molecular Evolution and Phylogenetics. Oxford University Press, UK.

Ni J., Wu P., Senadhira D. \& Huang N. (1998). Mapping QTLs for phosphorus deficiency tolerance in rice (Oryza sativa L.). Theoretical and Applied Genetics 97: 1361-1369. DOI: https://doi.org/10.1007/s001220051030

O'neil J., Davis T.W., Burford M.A. \& Gobler C. (2012). The rise of harmful cyanobacteria blooms: the potential roles of eutrophication and climate change. Harmful Algae 14: 313-334.

DOI: https://doi.org/10.1016/j.hal.2011.10.027

Pariasca-Tanaka J., Chin J.H., Dramé K.N., Dalid C., Heuer S. \& Wissuwa M. (2014). A novel allele of the P-starvation tolerance gene OSPSTOL1 from African rice (Oryza glaberrima Steud) and its distribution in the genus Oryza. Theoretical and Applied Genetics 127: 1387-1398. DOI: https://doi.org/10.1007/s00122-014-2306-y

Rambaut A. (2018). FigTree v1. 4.2, a graphical viewer of phylogenetic trees, 2014. Available at http://tree.bio.ed.ac. uk/software/figtree/. Accessed 11 July 2020.

Rice Research and Development Institute (RRDI) (2020). Recommended Varieties: Rice Cultivation. Available at www.doa.gov.lk/. Accessed 10 July 2020.

Rose T.J. \& Wissuwa M. (2012). Rethinking internal phosphorus utilization efficiency: a new approach is needed to improve PUE in grain crops. Advances in Agronomy 116: 186-211. DOI: https://doi.org/10.1016/B978-0-12-394277-7.00005-1

Sirisena D.N. \& Wanninayake W.M.N. (2014). Identification of promising rice varieties for low fertile soils in the low country intermediate zone in Sri Lanka. Annals of Sri Lanka, Department of Agriculture 14: 95-105.

Steen I. (1998). Phosphorus availability in the $21^{\text {st }}$ century: management of a non-renewable resource. Phosphorus and Potassium 217: 25-31.

Vandamme E., Rose T., Saito K., Jeong K. \& Wissuwa M. (2016). Integration of $P$ acquisition efficiency, $P$ utilization efficiency and low grain P concentrations into P-efficient rice genotypes for specific target environments. Nutrient Cycling in Agroecosystems 104(3): 413-427.

DOI: https://doi.org/10.1007/s10705-015-9716-3

Wang X., Liu F., Tan W., Li W., Feng X. \& Sparks D.L. (2013). Characteristics of phosphate adsorption-desorption onto ferrihydrite: comparison with well-crystalline Fe (hydr) oxides. Soil Science 178: 1-11.

DOI: https://doi.org/DOI: 10.1097/SS.0b013e31828683f8

Wissuwa M. \& Ae N. (2001). Genotypic variation for tolerance to phosphorus deficiency in rice and the potential for its exploitation in rice improvement. Plant Breeding 120: 43-48.

DOI: https://doi.org/10.1046/j.1439-0523.2001.00561.x

Wissuwa M., Wegner J., Ae N. \& Yano M. (2002). Substitution mapping of Pup1: a major QTL increasing phosphorus uptake of rice from a phosphorus-deficient soil. Theoretical and Applied Genetics 105: 890-897.

DOI: https://doi.org/10.1007/s00122-002-1051-9

Wissuwa M., Yano M. \& Ae N. (1998). Mapping of QTLs for phosphorus deficiency tolerance in rice (Oryza sativa L.). Theoretical and Applied Genetics 8(97): 777-783. DOI: https://doi.org/10.1007/s001220050955 